\title{
Amygdalin Attenuates Airway Epithelium Apoptosis, Inflammation, and Epithelial-Mesenchymal Transition through Restraining the TLR4/NF-kB Signaling Pathway on LPS-Treated BEAS-2B Bronchial Epithelial Cells
}

\author{
Zhenyang Si Biao Zhang \\ Department of Pediatrics, Nanjing Hospital of Chinese Medicine Affiliated to Nanjing University of Chinese Medicine, \\ Nanjing, China
}

\section{Keywords}

Amygdalin · Cough-variant asthma · Epithelium · Apoptosis . Inflammation - Epithelial-mesenchymal transition - Toll-like receptor 4/NF-KB signaling pathway

\begin{abstract}
Background: Cough-variant asthma (CVA) is a special type of asthma, solely manifesting with coughing. Studies suggest that airway inflammation is associated with CVA pathogenesis. Amygdalin is found to have an anti-inflammatory potential, while how it affects CVA remains unexplored. Methods: Cytotoxicity delivered by various concentrations of LPS and amygdalin on BEAS-2B cells was determined by Cell Counting Kit-8 assay. CVA in vitro models were established via LPS exposure on BEAS-2B cells which underwent amygdalin pretreatment. Cell apoptosis was determined by flow cytometry. Production of tumor necrosis factor (TNF)- $a$, interleukin (IL)-6, IL-8, and mucin 5AC (MUC5AC) in BEAS-2B cells was measured by ELISA and qRT-PCR. Expressions of TLR4, E-cadherin, N-cadherin, a-smooth muscle actin (SMA), vimentin, phosphorylated-p65 (p-p65), p65, phosphorylated$I \kappa B a(p-I \kappa B a)$, and I $\mathrm{KBa}$ in BEAS-2B cells were measured by qRT-PCR or Western blot. Results: LPS and high concentra-
\end{abstract}

karger@karger.com

(c) 2021 S. Karger AG, Basel

www.karger.com/iaa

Karger" ${ }^{\prime \prime}$ tions of amygdalin (over $600 \mu \mathrm{g} / \mathrm{mL}$ ) decreased BEAS-2B cell toxicity. Exposure to LPS inhibited toxicity, enhanced apoptosis; and promoted production of TNF- $a$, IL- 6 , IL-8, and MUC5AC, increased the levels of $\mathrm{N}$-Cadherin, a-SMA, vimentin, $\mathrm{p}-\mathrm{p} 65$, and $\mathrm{p}-\mathrm{I} \mathrm{KBa}$, and decreased the levels of E-cadherin and $\mathrm{I} \mathrm{KBa}$ in BEAS-2B cells. Amygdalin pretreatment counteracted the effects of LPS on BEAS-2B cells. Overexpressing TLR4 reversed amygdalin-exerted effects in LPS-exposed BEAS-2B cells. Conclusion: Amygdalin attenuated airway epithelium apoptosis, inflammation and epithelial-mesenchymal transition through restraining the TLR4/NF-KB signaling pathway in CVA.

(C) 2021 S. Karger AG, Basel

\section{Introduction}

Cough-variant asthma (CVA) is a special type of asthma and a frequent disease in children. The only or the main clinical manifestation of CVA arrives at coughing which is characterized by irritant cough in the morning

Edited by: H.-U. Simon, Bern.
Correspondence to:

Biao Zhang, zhangbiao_bzh@163.com 
or during the night [1]. A lack of timely and effective treatment may prompt some CVA to develop into childhood asthma [2]. Currently, the pathogenesis of CVA is not entirely clear. Nevertheless, existing theories indicate that regional bronchoconstriction, increased cough receptors' sensitivity, inflammation, and heightened vagal activity are contributing factors for CVA [3]. Cough reflex in CVA is complex and it involves the actions of peripheral receptors which are located in epithelial surface and can be stimulated by serotonin, bradykinin, nicotine, protons, capsaicin, ozone, and adenosine [3]. Exogenous deleterious factors like these may further evoke inflammatory responses in airway epithelium that functions as the primary defender of lung [4].

Airway inflammation can lead to damage and dysfunction of airway epithelial cells, which thereby aggravates the pathogenesis and progression of respiratory diseases [5]. Numerous studies designed for discovering drugs that alleviates airway inflammation demonstrated epithelial cell apoptosis and release of inflammatory factors in airway disease models [6]. Furthermore, long duration of inflammation in airways is correlated to a greater degree of airway remodeling $[7,8]$. Progressive remodeling can cause irreversible airway epithelial dysfunction [8]. Airway epithelial dysfunction resulting from damaged airway epithelial cells exhibited reduced epithelial cell adhesion with decreased epithelial markers and increased interstitial markers, hinting that epithelial-mesenchymal transition (EMT) is an important mechanism in airway remodeling [9]. Also, recent studies highlighted that EMT, a cell remodeling process where epithelial cells lose epithelial phenotypes, plays key roles in the progression of pulmonary diseases [10].

Recently, increasing attention has been drawn to the pharmaceutical potentials of amygdalin. Amygdalin, also known as interchangeably vitamin B17 or laetrile, is a cyano-containing glycoside compound derived from seeds of the Rosaceae family [11]. Studies on the pharmaceutical effects of amygdalin have shown that aside from the properties of cancer cell growth blocking and anti-atherosclerosis $[12,13]$, the prevalent activities exerted by amygdalin are inflammation relieving [14], cough suppression, and phlegm elimination [15]. However, how it affects CVA remains unexplored.

Moreover, emerging studies have revealed that manipulation on TLR4/NF-kB signaling ameliorated LPS-induced bronchial epithelial cell injury and inflammation [16]. However, the approaches to manipulating TLR4/ $\mathrm{NF}-\kappa \mathrm{B}$ signaling pathway for the objective of airway inflammation relieving remain insufficiently investigated.
In this research, we explored the mechanism by which amygdalin exerts anti-inflammatory effects and how the activation of the TLR4/NF- $\mathrm{BB}$ signaling pathway affects this mechanism in CVA. As LPS is applied to simulate asthmatic conditions in vitro [17], this study was conducted on bronchial epithelial cells under LPS-mimicked asthmatic condition.

\section{Materials and Methods}

\section{Cell Culture}

Human bronchial epithelial cells (BEAS-2B cells, CRL-9609) [16] were purchased from American Type Culture Collection (Manassas, VA, USA). The cells were housed in an atmosphere of $37^{\circ} \mathrm{C}$ and $5 \% \mathrm{CO}_{2}$ and cultured using BEGM Bronchial Epithelial Cell Growth Medium BulletKits (Lonza/Clonetics, Alpharetta, GA, USA).

\section{Drug Treatment}

Amygdalin (A6005, $\mathrm{C}_{20} \mathrm{H}_{27} \mathrm{NO}_{11}$, purity: $\geq 99 \%$ ) was purchased from Sigma-Aldrich (St. Louis, MO, USA) and dissolved in dimethyl sulfoxide (DMSO, D2650, Sigma-Aldrich, St. Louis, MO, USA). For preparation of working solutions used in cell pretreatment, amygdalin was diluted into solutions with various concentrations of $100,200,400,600$, and $1,000 \mu \mathrm{g} / \mathrm{mL}$. BEAS-2B cells were treated with the amygdalin working solutions for $24 \mathrm{~h}$ at $37^{\circ} \mathrm{C}$ with $5 \% \mathrm{CO}_{2}$, prior to CVA model establishment.

\section{LPS Exposure}

LPS (L2630, Sigma-Aldrich, St. Louis, MO, USA) were used for establish in vitro CVA models following amygdalin pretreatment. When BEAS-2B cells grew to $80 \%$ confluence, they were exposed to LPS at various concentrations $(1,5,10,25$, and $50 \mu \mathrm{g} / \mathrm{mL})$ or a specific concentration $(25 \mu \mathrm{g} / \mathrm{mL})$ for CVA model establishment for $24 \mathrm{~h}$ at $37^{\circ} \mathrm{C}$ with $5 \% \mathrm{CO}_{2}$.

\section{Cell Transfection}

TLR4 overexpression plasmid constructed using pcDNA3.1 vector was purchased from ThermoFisher (Waltham, MA, USA). Before amygdalin pretreatment and LPS exposure, BEAS-2B cells were transfected with TLR4 overexpression plasmid using Lipofectamine 3000 transfection reagent (L3000015, ThermoFisher, Waltham, MA, USA). Briefly, BEAS-2B cells were plated to be $3 \times$ $10^{4}$ cells/well in 96-well plates. Until the cell confluence reached $90 \%$ confluence, Lipofectamine 3000 transfection reagent and TLR4 overexpression plasmid were diluted by Opti-MEM medium (31985062, ThermoFisher, Waltham, MA, USA). All the diluted genes were first incubated with the diluted Lipofectamine 3000 transfection reagent at $37^{\circ} \mathrm{C}$ for $20 \mathrm{~min}$. The incubated solution was added into the cells, followed by the incubation with genelipid complex for $48 \mathrm{~h}$ at $37^{\circ} \mathrm{C}$.

\section{Cell Counting Kit-8 Assay}

The cytotoxicity induced by LPS and amygdalin on BEAS-2B cells was determined using Cell Counting Kit (CCK)-8 reagent (20140419, Beyotime, Beijing, China). BEAS-2B cells were seeded at $2 \times 10^{3}$ cells/well in 96-well plates. After TLR4 transfection, 
Table 1. Primers used in qRT-PCR for the target genes

\begin{tabular}{|c|c|c|c|}
\hline TNF- $\alpha$ & Human & 5'-ССТСТСТСТАATCAGCCCTCTG-3' & 5'-GAGGACCTGGGAGTAGATGAG-3' \\
\hline IL-6 & Human & 5'-ACTCACCTCTTCAGAACGAATTG-3' & 5'-CCATCTTTGGAAGGTTCAGGTTG-3' \\
\hline IL-8 & Human & 5'-TTTTGCCAAGGAGTGCTAAAGA-3' & 5'-AACCCTCTGCACCCAGTTTTC-3' \\
\hline MUC5AC & Human & 5'-TGCCCCTACAACAAGAACAAC-3' & 5'-GGAACAGCACTGGGAGTAGTT-3' \\
\hline TLR4 & Human & 5'-AGACCTGTCCCTGAACCCTAT-3' & 5'-CGATGGACTTCTAAACCAGCCA-3' \\
\hline E-cadherin & Human & 5'-CGAGAGCTACACGTTCACGG-3' & 5'-GGGTGTCGAGGGAAAAATAGG-3' \\
\hline a-SMA & Human & 5'-AAAAGACAGCTACGTGGGTGA-3' & 5'-GCCATGTTCTATCGGGTACTTC-3' \\
\hline Vimentin & Human & 5'-AGTCCACTGAGTACCGGAGAC-3' & 5'-CATTTCACGCATCTGGCGTTC-3' \\
\hline GAPDH & Human & 5'-GAGAAGGCTGGGGCTCATTT-3' & 5'-AGTGATGGCATGGACTGTGG-3' \\
\hline
\end{tabular}

TNF- $\alpha$, tumor necrosis factor- $\alpha$; IL-6, interleukin-6; IL-8, interleukin-8; MUC5AC, mucin 5AC; $\alpha$-SMA, $\alpha$-smooth muscle actin.

amygdalin pretreatment, and LPS exposure, CCK-8 reagent $(10$ $\mu \mathrm{L})$ was added into the seeded cells in each well, followed by incubation for $2 \mathrm{~h}$ at $37^{\circ} \mathrm{C}$ with $5 \% \mathrm{CO}_{2}$. Cell absorbance at $450 \mathrm{~nm}$ used as the indicator of cell toxicity was recorded by a microplate spectrophotometer (Epoch 2, BioTek, Winooski, VT, USA).

\section{Annexin V/Propidium Iodide Staining Assay}

After TLR4 transfection, amygdalin pretreatment, and LPS exposure, BEAS-2B cell apoptosis was determined using annexin $\mathrm{V}$ FITC/propidium iodide (PI) apoptosis detection kits (E-CK-A211, Elabscience, Shanghai, China, http://www.yeasen.com/products/ detail/944). Briefly, after being digested using Trypsin (PP0100, Sigma-Aldrich, St. Louis, MO, USA), BEAS-2B cells were centrifuged, washed by PBS, and last resuspended by binding buffer. Annexin V-FITC solution $(5 \mu \mathrm{L})$ and PI solution $(10 \mu \mathrm{L})$ were added for reaction in the cells for $20 \mathrm{~min}$ at room temperature in the darkness. Later, the cells were subjected to flow cytometer (Cytoflex, Beckman Coulter, Brea, CA, USA) and analyzed by CytExpert software (version 2.2.0.97, Beckman Coulter, Brea, CA, USA).

\section{Enzyme-Linked Immunosorbent Assay}

After TLR4 transfection, amygdalin pretreatment and LPS exposure, the production of tumor necrosis factor (TNF)- $\alpha$, interleukin (IL)-6, and IL-8 in BEAS-2B cells were measured by ELISA kits (KGEHC103a, KGEHC007, KGEHC008, Keygentec, Nanjing, China). Briefly, BEAS-2B cells was centrifuged at 2,000 $\mathrm{g}$ for 20 min for supernatant collection. The supernatant was added into enzyme-label coated plates, followed by incubation at $36^{\circ} \mathrm{C}$ for 90 min. Then, the biotinylated antibody was added into the plates, again followed by incubation at $36^{\circ} \mathrm{C}$ for $60 \mathrm{~min}$. Later, the enzyme-conjugated working solution were added into the plates, followed by incubation at $36^{\circ} \mathrm{C}$ for $30 \mathrm{~min}$. Last, the plates were incubated with color-developing reagent at $37^{\circ} \mathrm{C}$ for $15 \mathrm{~min}$. The reaction was terminated using $2 \mathrm{~mol} / \mathrm{L} \mathrm{H}_{2} \mathrm{SO}_{4}$. Optical density at 450 $\mathrm{nm}$, used as the indicator of production level, was measured under a microplate reader (ELx808, BioTek, Winooski, VT, USA)

Quantitative Reverse Transcription Polymerase Chain

Total RNA from BEAS-2B cells were isolated using Trizol reagent (15596026, ThermoFisher, Waltham, MA, USA). Chlo- roform (151858, Sigma-Aldrich, St. Louis, MO, USA) was used to stratify the RNA, which were then precipitated by isopropanol (I9516, Sigma-Aldrich), washed by 75\% ethanol (E7023, Sigma-Aldrich), and resuspended in RNase-free water (10977023, ThermoFisher). cDNA was synthesized using SuperScript IV reverse transcriptase (18090010, ThermoFisher) and amplified under a PCR detection System (CFX Connect, Bio-Rad, Philadelphia, PA, USA) using PowerUp SYBR Green Master Mix (A25742, ThermoFisher). The primers used were listed in Table 1. Real-time PCR reaction was initiated at $95^{\circ} \mathrm{C}$ predenaturation for $10 \mathrm{~min}, 95^{\circ} \mathrm{C}$ denaturation for $15 \mathrm{~s}$ and 40 circles of $95^{\circ} \mathrm{C}$ annealing for $15 \mathrm{~s}$, and $60^{\circ} \mathrm{C}$ elongation for $60 \mathrm{~s}$. The relative gene expressions were estimated by $2^{-\Delta \Delta \mathrm{Ct}}$ method [18].

\section{Western Blot}

Total protein lysates from BEAS-2B cells were obtained using RIPA Buffer (89900, ThermoFisher). The protein lysates were quantitated using BCA kits (A53227, ThermoFisher). Thirty-five $\mu \mathrm{g}$ of the protein lysates and $4 \mu \mathrm{L}$ of marker (PR1910, Solarbio, Beijing, China) were separately loaded, electrophoresed by $8 \%$ SDS-PAGE gel (P0051A, Beyotime, Shanghai, China). The electrophoresed protein lysates were transferred onto PVDF membranes (P2438, Sigma-Aldrich) and blocked using 5\% skim milk in Tris-Buffered Saline with 1\% Tween 20 (TBST, TA-125-TT, ThermoFisher) for $1 \mathrm{~h}$ at room temperature. Then, the membranes underwent overnight incubation at $4^{\circ} \mathrm{C}$ with primary antibodies for E-cadherin (ab40772, $97 \mathrm{kDa}, 1: 10,000$, Abcam, Cambridge, MA, USA), N-cadherin (ab18203, $130 \mathrm{kDa}, 1: 1,000$ ), a-smooth muscle actin (SMA) (ab5694, $42 \mathrm{kDa}, 1: 1,000)$, vimentin (ab92547, $54 \mathrm{kDa}, 1: 1,000)$, TLR4 (ab13867, $90 \mathrm{kDa}, 1: 500$ ), phosphorylated-p65 (p-p65) (ab86299, $60 \mathrm{kDa}, 1: 2,000)$, p65 (ab16502, $64 \mathrm{kDa}, 1: 1,000$, Abcam), phosphorylated-IкBa (p-IкBa) (\#2859S, $40 \mathrm{kDa}, 1: 1,000$, Cell Signaling, Beverly, MA, USA), IкBa (\#4814S, $39 \mathrm{kDa}, 1: 1,000$, Cell Signaling), and GAPDH (ab8245, $36 \mathrm{kDa}, 1: 500$, Abcam). Following washing with TBST, the membranes were incubated with Goat anti-Rabbit IgG (A32731, 1:10,000, ThermoFisher) or Goat anti-mouse IgG (A32733, 1:1,000, ThermoFisher). The protein bands were visualized using enhanced chemiluminescence reagent kit (WP20005, 


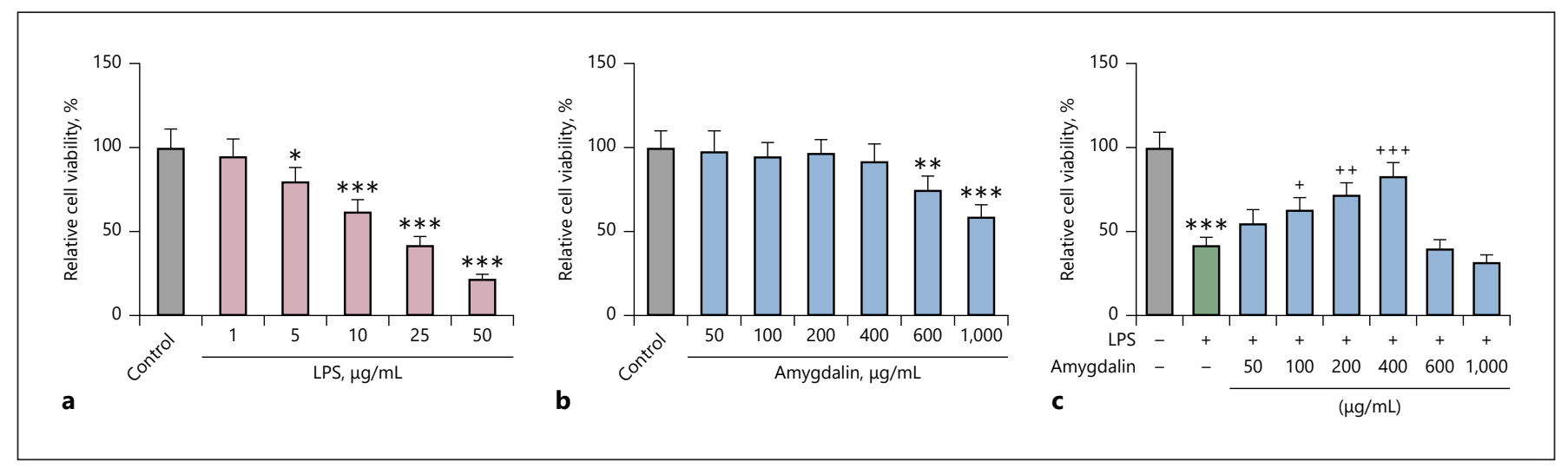

Fig. 1. Amygdalin and LPS might decrease BEAS-2B cell toxicity, and amygdalin counteracted an LPS-induced decreasing effect on BEAS-2B cell toxicity. a BEAS-2B cell toxicity was determined by CCK-8 assay after exposure to various concentrations of LPS $(0,1$, $5,10,25$, and $50 \mu \mathrm{g} / \mathrm{mL})$. b BEAS- 2 B cell toxicity was determined by CCK-8 assay after treatment with various concentrations of amygdalin $(0,50,100,200,400,600$, and $1,000 \mu \mathrm{g} / \mathrm{mL})$. c The toxicity of BEAS-2B cells pretreated with various concentrations of amygdalin $(0,50,100,200,400,600$, and $1,000 \mu \mathrm{g} / \mathrm{mL})$ was determined by CCK- 8 assay after exposure to LPS $(25 \mu \mathrm{g} / \mathrm{mL}) .{ }^{*} p$ or ${ }^{+} p<0.05 ;{ }^{* *} p$ or ${ }^{++} p<0.01 ;{ }^{* * *} p$ or ${ }^{+++} p<0.001 ;{ }^{*}$ versus control; ${ }^{+}$versus LPS. CCK-8, Cell Counting Kit-8; MUC5AC, mucin 5AC.
ThermoFisher) and analyzed by ImageJ software (1.52s version, National Institutes of Health, Bethesda, MA, USA).

\section{Statistical Analysis}

All data were presented as mean \pm SD. Statistical analysis was performed using GraphPad Prism (version 8.0, GraphPad Software Inc., San Diego, CA, USA). Comparison of differences among multiple groups was subjected to one-way ANOVA, and pairwise comparison of differences was subjected to Tamhane test. $p<0.05$ was considered statistically significant.

\section{Results}

LPS Might Decrease BEAS-2B Cell Toxicity, and Amygdalin Counteracted an LPS-Induced Decreasing Effect on BEAS-2B Cell Toxicity

For selection of an optimum concentration of LPS for establishment of in vitro models of CVA, BEAS-2B cells were exposed to increasing concentrations of LPS $(0,1,5$, $10,25$, and $50 \mu \mathrm{g} / \mathrm{mL})$. The results of cytotoxicity assay performed using CCK- 8 kits showed that exposure to LPS at $5,10,25$, and $50 \mu \mathrm{g} / \mathrm{mL}$ significantly decreased BEAS$2 \mathrm{~B}$ cell toxicity, compared to the LPS-unexposed cells $(p<0.05, p<0.001$, Fig. 1a). Then, the effect of amygdalin on BEAS-2B cell toxicity was examined though treatment with different concentrations of amygdalin $(0,50,100$, $200,400,600$, and $1,000 \mu \mathrm{g} / \mathrm{mL}$ ) on the cells. The results of CCK-8 assay showed that amygdalin treatment at 600 and $1,000 \mu \mathrm{g} / \mathrm{mL}$ decreased BEAS-2B cell toxicity, the other concentrations below $600 \mu \mathrm{g} / \mathrm{mL}$ produced no ob- vious effects on the toxicity, compared to the amygdalinuntreated cells $(p<0.01, p<0.001$; Fig. 1b). Subsequently, as LPS at $25 \mu \mathrm{g} / \mathrm{mL}$ ensured a pronounced cytotoxicity on BEAS-2B cells, it was chosen for establishment of in vitro models of CVA. After treatment with amygdalin at 100, 200 , and $400 \mu \mathrm{g} / \mathrm{mL}$, the toxicity of LPS-exposed BEAS$2 \mathrm{~B}$ cells exhibited a significant increase, compared to the cells without amygdalin treatment $(p<0.05, p<0.01, p<$ 0.001 ; Fig. 1c). All these results suggested a protective role of amygdalin on CVA.

\section{Amygdalin Counteracted LPS-Induced Apoptosis and} Inflammatory Responses in BEAS-2B Cells

Next, amygdalin at 200 and $400 \mu \mathrm{g} / \mathrm{mL}$ that produce no obvious cytotoxicity to the BEAS-2B cells was used to treat the cells, for investigation of the effect of amygdalin on apoptosis and inflammatory factor release in CVA. BEAS-2B cell apoptosis was determined using annexin V-FITC/PI staining analysis. The results of flow cytometry showed that BEAS-2B cell apoptosis was enhanced under exposure to LPS $(p<0.001)$, while the BEAS-2B cell apoptosis following exposure to LPS was inhibited by treatment with amygdalin $(p<0.01, p<0.001$; Fig. 2a, b).

Besides that, inflammation was also a frequent consequence in asthma. Previous studies have maintained that an increased level of MUC5AC, a proverbial mucus protein which contributes to the mucous phenotypes, is critical to inflammatory response induction in asthma [19, 20]. Thus, we deciphered how amygdalin affects the pro- 


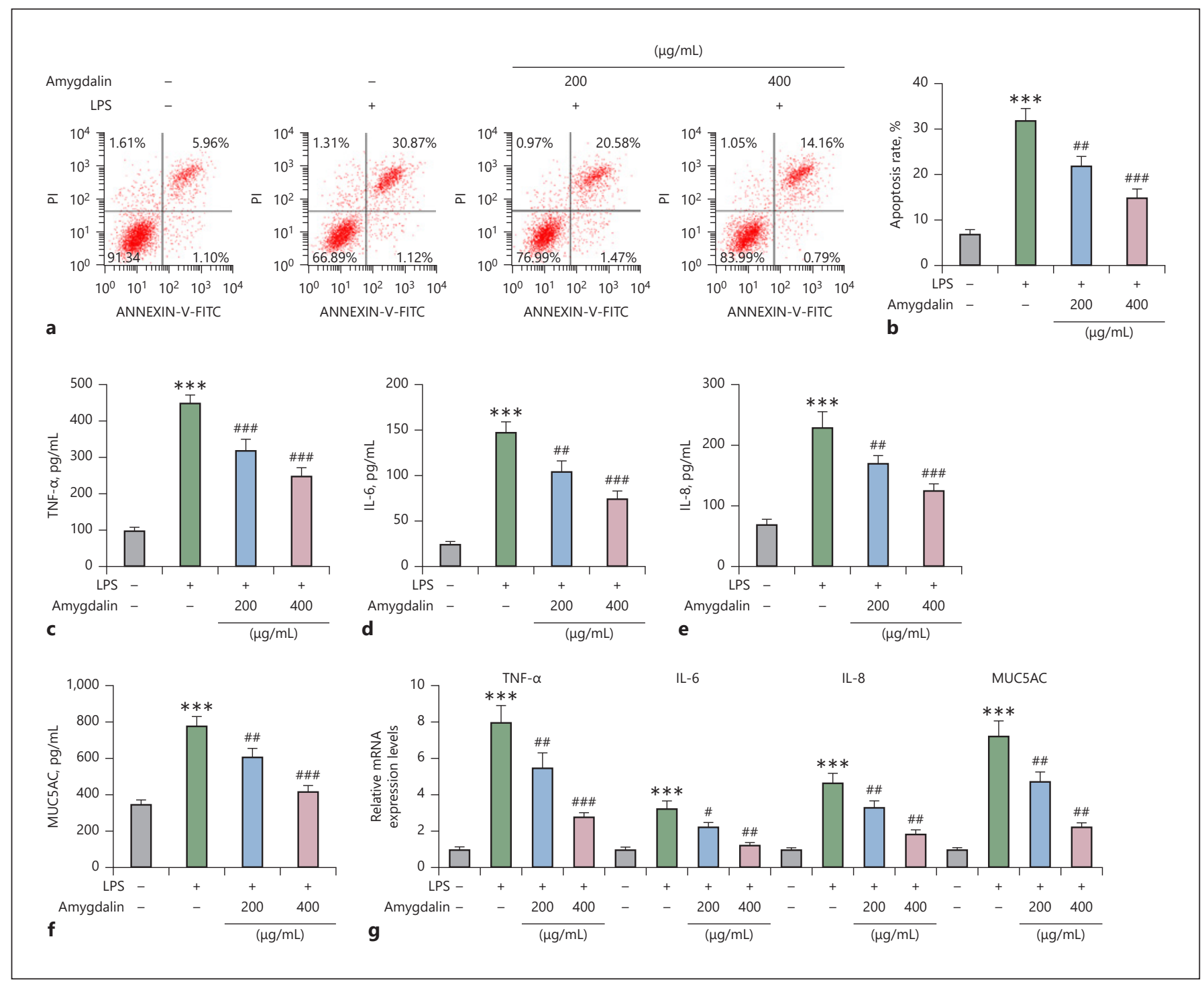

Fig. 2. Amygdalin counteracted LPS-induced apoptosis and inflammatory responses in BEAS-2B cells. $\mathbf{a}, \mathbf{b}$ The apoptosis of BEAS-2B cells pretreated with amygdalin $(200$ and $400 \mu \mathrm{g} / \mathrm{mL})$ was determined by flow cytometry after exposure to LPS $(25 \mu \mathrm{g} / \mathrm{mL})$. c-f The levels of TNF- $\alpha$, IL-6, IL-8, and MUC5AC in BEAS-2B cells pretreated with amygdalin $(200$ and $400 \mu \mathrm{g} / \mathrm{mL})$ was measured by ELISA after exposure to LPS $(25 \mu \mathrm{g} / \mathrm{mL})$. g The mRNA expressions of TNF- $\alpha$, IL-6, IL-8, and MUC5AC in BEAS-2B cells pretreated with amygdalin $(200$ and $400 \mu \mathrm{g} / \mathrm{mL})$ were analyzed by qRT-PCR after exposure to LPS $(25 \mu \mathrm{g} / \mathrm{mL}) .{ }^{*} p<0.05 ;{ }^{* *} p<0.01$; ${ }^{* * *} p$ or ${ }^{\# \#} p<0.001$; *versus Control; ${ }^{*}$ versus LPS. TNF- $\alpha$, tumor necrosis factor- $\alpha$; IL-6, interleukin-6; IL-8, interleukin-8; MUC5AC, mucin 5AC; $\alpha$-SMA, $\alpha$-smooth muscle actin. duction of inflammatory factors, including TNF- $\alpha$, IL-6, IL-8, as well as MUC5AC in CVA. The results of ELISA assay and qRT-PCR analyses revealed that the levels and mRNA expressions of TNF- $\alpha$, IL-6, IL-8, and MUC5AC in BEAS-2B cells were increased after exposure to LPS, while treatment with amygdalin inhibited those levels and expressions in LPS-exposed BEAS-2B cells $(p<0.01$, $p<0.001$; Fig. 2c-g).

Effects of Amygdalin on Cough-Variant Asthma

\section{Amygdalin Counteracted LPS-Induced EMT and Activation of TLR4/NF-Kb Signaling in BEAS-2B Cells}

EMT, a cell remodeling process where epithelial cells lose epithelial phenotypes, is associated with the progression of chronic obstructive pulmonary disease [21]. We therefore examined the expressions of EMT-specific markers in CVA. The results of Western blot confirmed 
that exposure to LPS led to downregulation of E-cadherin and upregulation of $\mathrm{N}$-cadherin, $\alpha$-SMA, and vimentin in BEAS-2B cells $(p<0.001)$, while treatment with amygdalin upregulated E-cadherin and downregulated N-cadherin, $\alpha$-SMA, and vimentin in LPS-exposed BEAS-2B cells $(p<0.05, p<0.01$; Fig. 3a, b). Moreover, recent studies have demonstrated increased activation of the TLR4/
NF- $\kappa \mathrm{B}$ signaling pathway in asthmatic mice [22]. To determine whether CVA is driven by the activation of TLR4/ $\mathrm{NF}-\kappa \mathrm{B}$ signaling pathway, the pathway related-markers was examined. The results of Western blot revealed that the levels of TLR4 and p-p65 and p-IкBa were increased, and $\mathrm{I} \kappa \mathrm{B} \alpha$ level and the ratios of $\mathrm{p}-\mathrm{p} 65$ to $\mathrm{p} 65$ and $\mathrm{p}-\mathrm{I} \kappa \mathrm{B} \alpha$ to I $\mathrm{B} a$ were decreased in BEAS-2B cells after exposure

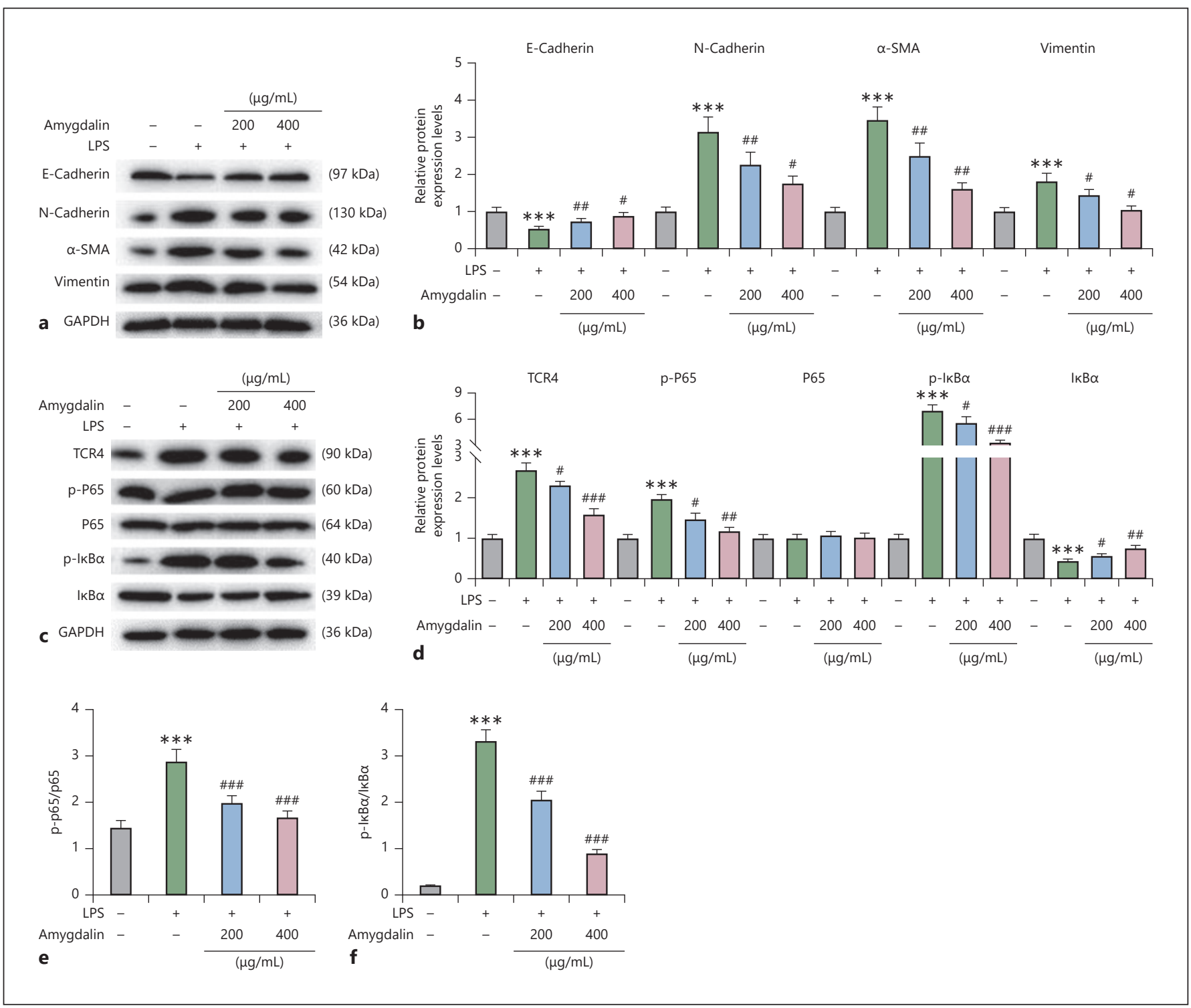

Fig. 3. Amygdalin counteracted LPS-induced EMT and activation of TLR4/NF- $\kappa \mathrm{B}$ signaling in BEAS-2B cells. a, b The protein expressions of E-cadherin, $\mathrm{N}$-cadherin, $\alpha$-SMA, and vimentin in $\mathrm{BE}$ AS-2B cells pretreated with amygdalin $(200$ and $400 \mu \mathrm{g} / \mathrm{mL})$ after exposure to LPS $(25 \mu \mathrm{g} / \mathrm{mL})$ were analyzed by Western blot, with GAPDH serving as a reference gene. $\mathbf{c}$, $\mathbf{d}$ The protein expressions

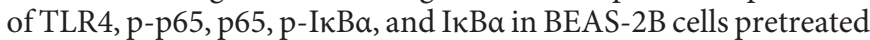

with amygdalin (200 and $400 \mu \mathrm{g} / \mathrm{mL})$ after exposure to LPS (25 $\mu \mathrm{g} /$ $\mathrm{mL}$ ) were analyzed by Western blot, with GAPDH serving as a ref-

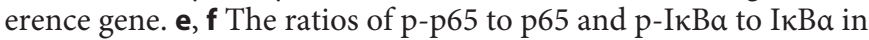
BEAS-2B cells pretreated with amygdalin $(200$ and $400 \mu \mathrm{g} / \mathrm{mL})$ after exposure to LPS $(25 \mu \mathrm{g} / \mathrm{mL}){ }^{\#} p<0.05 ;{ }^{* *} p$ or ${ }^{\# \#} p<0.01$; ${ }^{* * *} p$ or ${ }^{\# \#} p<0.001 ;{ }^{*}$ versus control; ${ }^{\#}$ versus LPS. $p$-p 65 , phosphorylated-

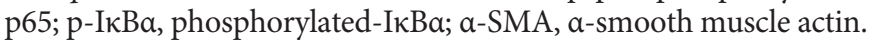




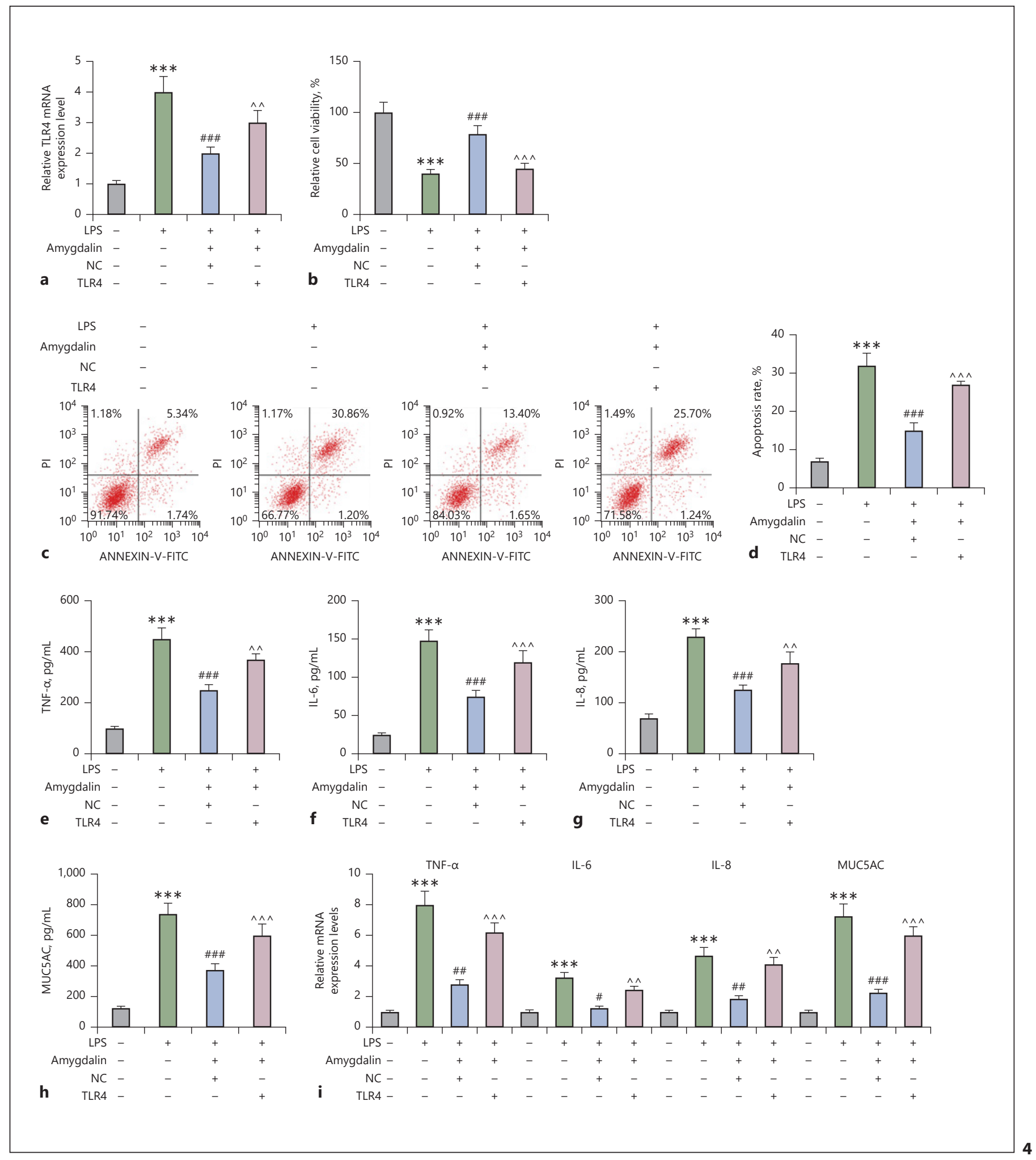

(For legend see next page.) 
to LPS $(p<0.001)$, while treatment with amygdalin resulted in decreased levels of TLR4 and p-p65 and p-IкBa, an increased IкBa level, and reduced ratios of p-p65 to p65 and $\mathrm{p}$-I $\mathrm{B} \mathrm{B} a$ to I $\mathrm{KB} \alpha$ in LPS-exposed BEAS-2B cells $(p<0.05, p<0.01 ; p<0.001$, Fig. 3a-f). These results suggested that the protective effects of amygdalin on LPSinjury BEAS-2B cells were exerted through inhibiting EMT and the TLR4/NF- $\kappa B$ signaling pathway.

\section{Overexpressing TLR4 Reversed Amygdalin-Exerted}

Effects on Toxicity, Apoptosis, and Inflammatory

Responses via TLR4/NF-Kb Signaling in LPS-Exposed

BEAS-2B Cells

For verification on the notion that the inhibition of the TLR4/NF- $\kappa \mathrm{B}$ signaling pathway is indispensable in the effects exerted by amygdalin against CVA, TLR4 overexpression plasmid was utilized to promote the activation of the TLR4/NF- $\kappa \mathrm{B}$ signaling pathway. Transfection of TLR4 overexpression plasmid led to an increased TLR4 expression, compared to the LPS + amygdalin + NC group $(p<0.01)$, and it reversed the amygdalin-exerted promotive effect on LPS-decreased BEAS-2B cell toxicity and the amygdalin-exerted inhibitory effect on LPS-enhanced apoptosis ( $p<0.001$; Fig. $4 a-d)$. Furthermore, amygdalin-exerted inhibitory effect on LPS-induced production of TNF- $\alpha$, IL-6, IL-8, and MUC5AC was also reversed by transfection of TLR4 overexpression plasmid $(p<0.01, p<0.001$; Fig. 4a-d). Simultaneously, transfection of TLR4 overexpression plasmid reversed the amygdalin-exerted inhibitory effect on LPS-upregulated Ncadherin, a-SMA, and vimentin, and it reversed the amygdalin-exerted promotive effect on LPS-downregulated E-cadherin $(p<0.05, p<0.01, p<0.001$; Fig. 5a, b). Besides, transfection of TLR 4 overexpression plasmid increased the levels of p-p65 and p-IкBa, raised the ratios

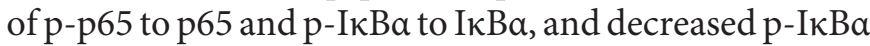
level during amygdalin treatment on LPS-injured BEAS2 B cells $(p<0.05, p<0.001$; Fig. $5 c$, d).

Fig. 4. Overexpressing TLR4 reversed amygdalin-exerted effects on toxicity, apoptosis, and inflammatory responses in LPS-exposed BEAS-2B cells. a TLR4 mRNA expression in TLR4 overexpression plasmid-transfected BEAS-2B cells after pretreatment with amygdalin $(200$ and $400 \mu \mathrm{g} / \mathrm{mL})$ and exposure to LPS $(25 \mu \mathrm{g} /$ $\mathrm{mL}$ ) was analyzed by qRT-PCR. $\mathbf{b}$ The toxicity of TLR4 overexpression plasmid-transfected BEAS-2B cells after pretreatment with amygdalin $(200$ and $400 \mu \mathrm{g} / \mathrm{mL})$ and exposure to LPS $(25 \mu \mathrm{g} /$ $\mathrm{mL}$ ) was determined by CCK-8 assay. c, $\mathbf{d}$ The apoptosis of TLR4 overexpression plasmid-transfected BEAS-2B cells after pretreatment with amygdalin $(200$ and $400 \mu \mathrm{g} / \mathrm{mL})$ and exposure to LPS $(25 \mu \mathrm{g} / \mathrm{mL})$ was determined by flow cytometry. $\mathbf{e}-\mathbf{h}$ The levels of

\section{Discussion}

CVA, considered as the precursor of classic asthma, has some clinical profiles that are the same as classic asthma dose, demonstrating eosinophilic inflammation of bronchi and sputum eosinophilia [23]. Existing guidelines for treatment of CVA as well as CA recommend that CVA patients should resort to inhalation of corticosteroids and bronchodilators [24]. However, inhaling highdose of bronchodilators and corticosteroids can elicit vascular remodeling effects, which may include side effects that thus aggravate symptoms [25]. Therefore, discovering a natural occurring agent that harbors less adverse effects during treatment of CVA is of great importance. In this study, we demonstrated that amygdalin, a traditional herbal medicine, could increase toxicity, inhibit apoptosis, reduce production of inflammatory factors and mucus protein, and inhibit EMT in LPS-injured epithelial cells through inhibition of the TLR4/NF- $\mathrm{KB}$ signaling pathway.

Epithelial cell damage can result from airway inflammation which is a distinct pathological feature of asthma [26]. Accumulating studies have confirmed that exposure to LPS causes airway inflammation and injury $[17,27]$. Our study applied various concentrations of LPS on BEAS-2B cells to find out $25 \mu \mathrm{g} / \mathrm{mL}$ as the optimum concentration of LPS for establishment of CVA models. Recent studies set for finding cures for pulmonary disease have illustrated that treatment with $<600 \mu \mathrm{g} / \mathrm{mL}$ of amygdalin has no effects on BEAS-2B cell toxicity, and the concentration over $600 \mu \mathrm{g} / \mathrm{mL}$ delivers an inhibitory effect on the viability [28]. Replicating these findings, our study again showed that $400 \mu \mathrm{g} / \mathrm{mL}$ was the highest concentration of amygdalin, which did not reduce toxicity of BEAS-2B cells. Furthermore, amygdalin is found to counteract cigarette smoke-delivered negative effect on cell viability [28]. Similarly, following the establishment of CVA models, we found that treatment with amygdalin at lower than

TNF- $\alpha$, IL-6, IL-8, and MUC5AC in TLR4 overexpression plasmid-transfected BEAS-2B cells after pretreatment with amygdalin (200 and $400 \mu \mathrm{g} / \mathrm{mL})$ and exposure to LPS $(25 \mu \mathrm{g} / \mathrm{mL})$ were measured by ELISA. i The mRNA expressions of TNF- $\alpha$, IL- 6 , IL- 8 , and MUC5AC in TLR4 overexpression plasmid-transfected BEAS- $2 B$ cells after pretreatment with amygdalin (200 and $400 \mu \mathrm{g} /$ $\mathrm{mL})$ and exposure to LPS $(25 \mu \mathrm{g} / \mathrm{mL})$ were analyzed by qRT-PCR. ${ }^{\#} p<0.05 ;{ }^{\# \#} p$ or ${ }^{\wedge \wedge} p<0.01 ;{ }^{* * *} p$ or ${ }^{\# \# \#} p$ or ${ }^{\wedge \wedge \wedge} p<0.001 ;{ }^{*}$ versus control; " versus LPS; ${ }^{\wedge}$ versus LPS + amygdalin + NC. TNF- $\alpha$, tumor necrosis factor- $\alpha$; IL-6, interleukin-6; IL-8, interleukin-8; MUC5AC, mucin 5AC; CCK-8, Cell Counting Kit-8. 
$400 \mu \mathrm{g} / \mathrm{mL}$ promoted the toxicity of CVA model cells. Besides, both airway epithelial inflammation and dysfunction in allergic asthma and exposure to LPS were found to induce cell apoptosis $[29,30]$. Analogously, our study demonstrated an apoptosis-inducing effect of LPS. Notably, we found that after amygdalin treatment LPSinduce apoptosis was repressed.

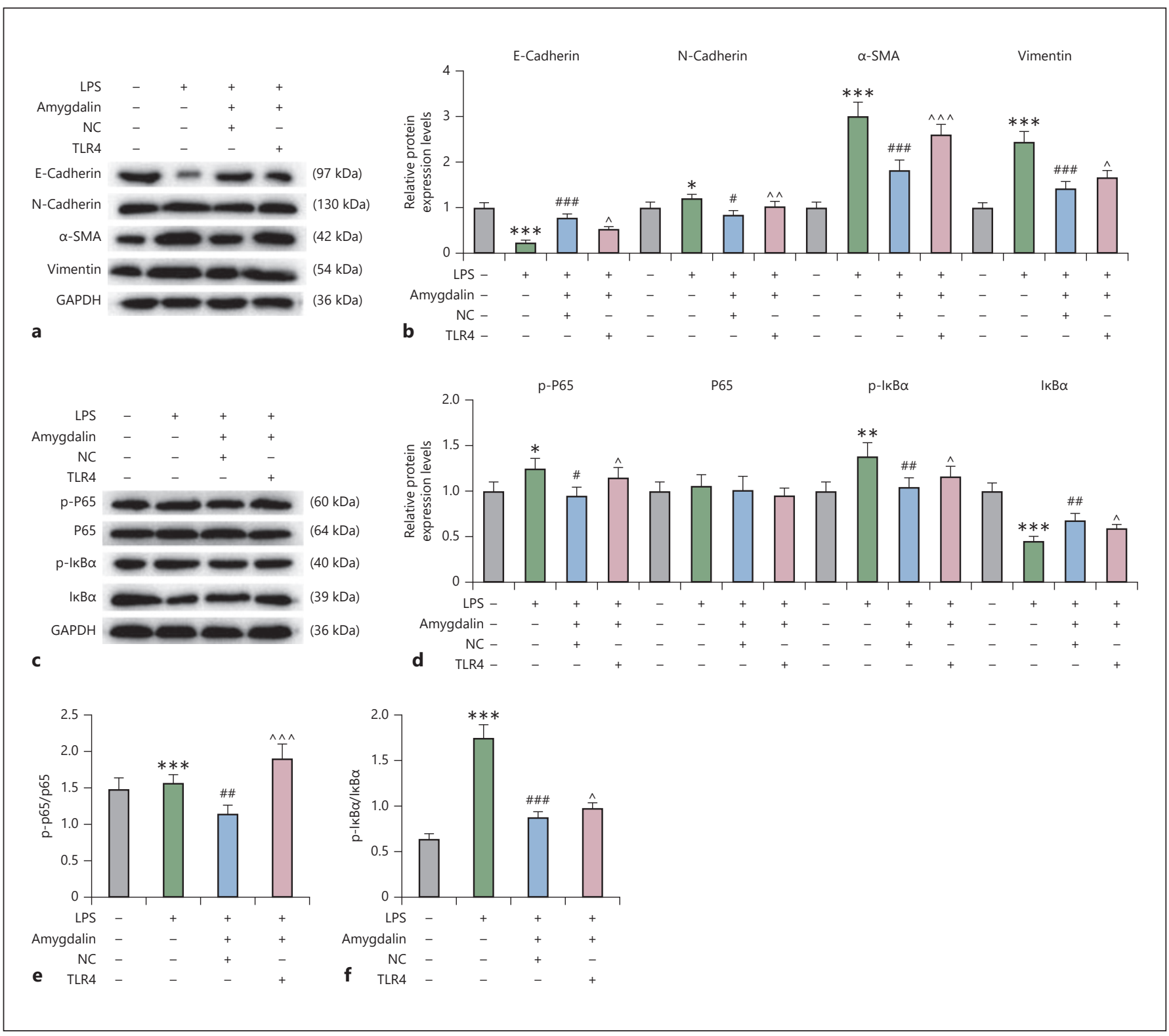

Fig. 5. Overexpressing TLR4 reversed amygdalin-exerted effects on EMT and activation of TLR4/NF- $\kappa \mathrm{B}$ signaling in LPS-exposed BEAS- $2 \mathrm{~B}$ cells. $\mathbf{a}, \mathbf{b}$ The protein expressions of E-cadherin, N-cadherin, a-SMA, and vimentin in TLR4 overexpression plasmidtransfected BEAS-2B cells after pretreatment with amygdalin (200 and $400 \mu \mathrm{g} / \mathrm{mL})$ and exposure to LPS $(25 \mu \mathrm{g} / \mathrm{mL})$ were analyzed by Western blot, with GAPDH serving as a reference gene. c, d The protein expressions of TLR4, p-p65, p65, p-I $\mathrm{KB} \alpha$, and $\mathrm{I} \kappa \mathrm{B} \alpha$ in TLR4 overexpression plasmid-transfected BEAS-2B cells after pre- treatment with amygdalin $(200$ and $400 \mu \mathrm{g} / \mathrm{mL})$ and exposure to LPS $(25 \mu \mathrm{g} / \mathrm{mL})$ were analyzed by Western blot, with GAPDH serving as a reference gene. e, $\mathbf{f}$ The ratios of p-p65 to p65 and $\mathrm{p}-\mathrm{I} \kappa \mathrm{B} \alpha$ to I $\mathrm{I} \mathrm{B} \alpha$ in TLR4 overexpression plasmid-transfected BEAS-2B cells after pretreatment with amygdalin $(200$ and $400 \mu \mathrm{g} /$ $\mathrm{mL})$ and exposure to LPS $(25 \mu \mathrm{g} / \mathrm{mL}) ;{ }^{*} p$ or ${ }^{\#} p$ or ${ }^{\wedge} p<0.05 ;{ }^{\# \#} p$ or ${ }^{\wedge \wedge} p<0.01 ;{ }^{* * *} p$ or ${ }^{\# \# \#} P$ or ${ }^{\wedge \wedge} p<0.001$; *versus control; ${ }^{\#}$ versus LPS; ${ }^{\wedge}$ versus LPS + amygdalin + NC. p-p65, phosphorylated-p65; $\mathrm{p}-\mathrm{I} \kappa \mathrm{B} \alpha$, phosphorylated-I $\mathrm{B} \alpha$; $\alpha$-SMA, $\alpha$-smooth muscle actin. 
Recent therapeutic strategies that target airway inflammation have been considered as effective to antagonize inflammatory lung pathologies in asthma [31]. Epithelial cells isolated from asthmatic patients displayed promoted release of IL-8 and TNF- $\alpha$ [32]. Meanwhile, markedly increased existence of sputum in the airways has been found in patients with CVA [33]. MUC5AC is a glycoprotein constituting airway mucus [20]. Mucus obstruction can form nutrient-rich nidi for bacterial infections that can trigger neutrophilic airway inflammation [34]. As reported in Shang's studies, LPS-induced in vitro models exhibited releases of TNF- $\alpha$, IL- 6 , and IL- 8 and increased production of MUC5AC, while anti-inflammatory treatment reversed theses phenomena [16]. In addition, EMT is thought to account for airway hyperresponsiveness and remodeling [35]. In our study, LPS induction also caused releases of these inflammatory factors, increased MUC5AC level, and promoted EMT as reflected by aberrantly expressed EMT-specific markers (E-cadherin, N-cadherin, $a$-SMA, and vimentin). Amygdalin treatment was found by us to reverse all these LPS-induced effects, which confirmed the anti-inflammatory and EMT property of amygdalin.

Previous studies have shown that inhibiting the NF- $\mathrm{kB}$ signaling pathway is a mechanism by which amygdalin suppresses inflammation in acute lung injury [36]. Shang's study has found that restraining the TLR4/NF- $\kappa B$ signaling results in suppression on LPS-induced epithelial cell injury and inflammation, which is accompanied by repressed expressions of TLR4 and p-p65 [16]. TLR4, one of the TLRs that recognizes a variety of pathogenassociated molecular patterns [37], is found to be activated by LPS to basically trigger all the responses to LPS [38]. TLR4 receptor can elicit the activation of NF- $\mathrm{BB}$ pathway to thereby unleash inflammatory factors [39]. $\mathrm{NF}-\kappa \mathrm{B}$, a transcription factor which is key to inflammatory responses, controls the final immune response through regulating the expressions of inflammatory cytokines and chemokines [40, 41]. Our study found that amygdalin treatment decreased LPS-induced expressions of TLR4, p-p65, and p-IкBa and increased LPS-antagonized expression of I $\kappa \mathrm{B} \alpha$ (a NF- $\kappa \mathrm{B}$ inhibitor), suggesting that anti-inflammatory effect of amygdalin can be exerted through inhibiting the TLR4/NF- $\mathrm{kB}$ signaling. Subsequently, for verification on the necessity of the inhibition of the TLR4/NF- $\mathrm{kB}$ signaling pathway in amygdalin-induced anti-inflammatory and EMT activities, we overexpressed TLR4 to activate this pathway. Our result showed that overexpressing TLR4 attenuated the effect of amygdalin.
The validation of amygdalin functioning on CVA using other cell lines, animal models, or the important proteins/pathways in patients would be conducted in future, which might be limitations of this research.

In conclusion, amygdalin increased epithelial cell viability by inhibiting the activation of NF- $\kappa$ B through TLR4. Thereby, amygdalin also reduced apoptosis, EMT, and the synthesis of proinflammatory cytokines. The research might put forward an effective therapeutic agent for airway injury in CVA.

\section{Statement of Ethics}

No humans or animals were involved in this research.

\section{Conflict of Interest Statement}

The authors declare no conflicts of interest.

\section{Funding Sources}

This work was supported by the Jiangsu Provincial Administration of Traditional Chinese Medicine (LZ13100), the Nanjing Medical Science and Technology Development Fund (QRX17188), and Famous TCM Studio of Zhangbiao (ZB-2017-NJ).

\section{Author Contributions}

Substantial contributions to conception and design: Z.S. Data acquisition, data analysis and interpretation: B.Z. Drafting the manuscript or critically revising it for important intellectual content: all authors. Final approval of the version to be published: all authors. Agreement to be accountable for all aspects of the work in ensuring that questions related to the accuracy or integrity of the work are appropriately investigated and resolved: all authors.

\section{References}

1 Niimi A. Cough variant asthma. Nihon Rinsho. 2016 Oct;74(10):1693-7.

2 Li W, Ban C, Zhang J, Hu Y, Han B, Han B. Correlation study of cough variant asthma and mycoplasma pneumonia infection in children. Pak J Pharm Sci. 2017 May;30(3 Special):1099-102.

3 Corrao WM. Pearls and pitfalls in the diagnosis of cough variant asthma. Allergy Asthma Proc. 2018 Nov 1;39(6):466-7.

4 Kumari A, Dash D, Singh R. Lipopolysaccharide (LPS) exposure differently affects allergic asthma exacerbations and its amelioration by intranasal curcumin in mice. Cytokine. 2015 Dec;76(2):334-42.
Si/Zhang 
5 Sun J, Huang N, Ma W, Zhou H, Lai K. Protective effects of metformin on lipopolysaccharide-induced airway epithelial cell injury via NF- $\kappa B$ signaling inhibition. Mol Med Rep. 2019 Mar;19(3):1817-23.

6 Caglayan Sozmen S, Karaman M, Cilaker Micili S, Isik S, Bagriyanik A, Arikan Ayyildiz Z, et al. Effects of quercetin treatment on epithelium-derived cytokines and epithelial cell apoptosis in allergic airway inflammation mice model. Iran J Allergy Asthma Immunol. 2016 Dec;15(6):487-97.

7 Pepe C, Foley S, Shannon J, Lemiere C, Olivenstein R, Ernst $\mathrm{P}$, et al. Differences in airway remodeling between subjects with severe and moderate asthma. J Allergy Clin Immunol. 2005 Sep;116(3):544-9.

8 Kaminska M, Foley S, Maghni K, StornessBliss C, Coxson $\mathrm{H}$, Ghezzo $\mathrm{H}$, et al. Airway remodeling in subjects with severe asthma with or without chronic persistent airflow obstruction. J Allergy Clin Immunol. 2009 Jul; 124(1):45-4.

9 Moheimani F, Hsu AC, Reid AT, Williams T, Kicic A, Stick SM, et al. The genetic and epigenetic landscapes of the epithelium in asthma. Respir Res. 2016 Sep 22;17(1):119.

10 Jolly MK, Ward C, Eapen MS, Myers S, Hallgren $\mathrm{O}$, Levine $\mathrm{H}$, et al. Epithelial-mesenchymal transition, a spectrum of states: role in lung development, homeostasis, and disease. Dev Dyn. 2018 Mar;247(3):346-58

11 Todorova A, Pesheva M, Iliev I, Bardarov K, Todorova T. Antimutagenic, antirecombinogenic, and antitumor effect of amygdalin in a yeast cell-based test and mammalian cell lines. J Med Food. 2017 Apr;20(4):360-6.

12 Jiagang D, Li C, Wang H, Hao E, Du Z, Bao C, et al. Amygdalin mediates relieved atherosclerosis in apolipoprotein $\mathrm{E}$ deficient mice through the induction of regulatory $\mathrm{T}$ cells Biochem Biophys Res Commun. 2011 Aug 5; 411(3):523-9.

13 Makarević J, Rutz J, Juengel E, Kaulfuss S, Reiter M, Tsaur I, et al. Amygdalin blocks bladder cancer cell growth in vitro by diminishing cyclin A and cdk2. PLoS One. 2014;9(8): e105590.

14 Hwang HJ, Lee HJ, Kim CJ, Shim I, Hahm DH. Inhibitory effect of amygdalin on lipopolysaccharide-inducible TNF-alpha and IL1beta mRNA expression and carrageenan-induced rat arthritis. J Microbiol Biotechnol. 2008 Oct;18(10):1641-7.

15 He XY, Wu LJ, Wang WX, Xie PJ, Chen YH, Wang F. Amygdalin - A pharmacological and toxicological review. J Ethnopharmacol. 2020 May 23;254:112717.

16 Shang J, Liu W, Yin C, Chu H, Zhang M. Cucurbitacin $\mathrm{E}$ ameliorates lipopolysaccharideevoked injury, inflammation and MUC5AC expression in bronchial epithelial cells by restraining the HMGB1-TLR4-NF- $\kappa B$ signaling. Mol Immunol. 2019 Oct;114:571-7.
17 Elaidy SM, Essawy SS, Hussain MA, El-Kherbetawy MK, Hamed ER. Modulation of the IL-23/IL-17 axis by fenofibrate ameliorates the ovalbumin/lipopolysaccharide-induced airway inflammation and bronchial asthma in rats. Naunyn Schmiedebergs Arch Pharmacol. 2018 Mar;391(3):309-21.

18 Livak KJ, Schmittgen TD. Analysis of relative gene expression data using real-time quantitative PCR and the 2(-delta delta $\mathrm{C}(\mathrm{T})$ ) method. Methods. 2001 Dec;25(4):402-8.

19 Fahy JV, Dickey BF. Airway mucus function and dysfunction. N Engl J Med. 2010 Dec 2; 363(23):2233-47.

20 Evans CM, Raclawska DS, Ttofali F, Liptzin DR, Fletcher AA, Harper DN, et al. The polymeric mucin Muc5ac is required for allergic airway hyperreactivity. Nat Commun. 2015 Feb 17;6:6281.

21 Gohy ST, Hupin C, Fregimilicka C, Detry BR, Bouzin C, Gaide Chevronay H, et al. Imprinting of the COPD airway epithelium for dedifferentiation and mesenchymal transition. Eur Respir J. 2015 May;45(5):1258-72.

22 Zhang H, Yang N, Wang T, Dai B, Shang Y. Vitamin $D$ reduces inflammatory response in asthmatic mice through HMGB1/TLR4/NF$\kappa \mathrm{B}$ signaling pathway. Mol Med Rep. 2018 Feb;17(2):2915-20.

23 Lougheed MD, Turcotte SE, Fisher T. Cough variant asthma: lessons learned from deep inspirations. Lung. 2012 Feb;190(1):17-22.

24 Kanemitsu Y, Niimi A, Matsumoto H, Iwata T, Ito I, Oguma T, et al. Gastroesophageal dysmotility is associated with the impairment of cough-specific quality of life in patients with cough variant asthma. Allergol Int. 2016 Jul;65(3):320-6.

25 Lanza GM, Jenkins J, Schmieder AH, Moldobaeva A, Cui G, Zhang H, et al. Anti-angiogenic nanotherapy inhibits airway remodeling and hyper-responsiveness of dust mite triggered asthma in the Brown Norway Rat. Theranostics. 2017;7(2):377-89.

26 Kim MS, Cho KA, Cho YJ, Woo SY. Effects of interleukin-9 blockade on chronic airway inflammation in murine asthma models. Allergy Asthma Immunol Res. 2013 Jul;5(4):197206.

27 Lowe APP, Thomas RS, Nials AT, Kidd EJ, Broadley KJ, Ford WR. Route of administration affects corticosteroid sensitivity of a combined ovalbumin and lipopolysaccharide model of asthma exacerbation in guinea pigs. J Pharmacol Exp Ther. 2017 Aug;362(2):32737.

28 Wang Z, Fang K, Wang G, Guan X, Pang Z, Guo Y, et al. Protective effect of amygdalin on epithelial-mesenchymal transformation in experimental chronic obstructive pulmonary disease mice. Phytother Res. 2019 Mar;33(3): 808-17.

29 Divya P, Puthusseri B, Manual DJK, Savanur MA. Epigallocatechin gallate protects BEAS-
2B cells from lipopolysaccharide-induced apoptosis through upregulation of gastrin-releasing peptide. Mol Cell Biochem. 2017 Oct; 434(1-2):105-11.

30 Lv J, Su W, Yu Q, Zhang M, Di C, Lin X, et al. Heme oxygenase-1 protects airway epithelium against apoptosis by targeting the proinflammatory NLRP3-RXR axis in asthma. J Biol Chem. 2018 Nov 30;293(48): 18454-65.

31 Li HY, Meng JX, Liu Z, Liu XW, Huang YG, Zhao J. Propofol attenuates airway inflammation in a mast cell-dependent mouse model of allergic asthma by inhibiting the toll-like receptor 4/reactive oxygen species/nuclear factor $\mathrm{\kappa B}$ signaling pathway. Inflammation. 2018 Jun;41(3):914-23.

32 De Diego A, Martínez E, Perpiñá M, Nieto L, Compte L, Macián V, et al. Airway inflammation and cough sensitivity in cough-variant asthma. Allergy. 2005 Nov;60(11):1407-11.

33 Niimi A, Amitani R, Suzuki K, Tanaka E, Murayama T, Kuze F. Eosinophilic inflammation in cough variant asthma. Eur Respir J. 1998 May;11(5):1064-9.

34 Balázs A, Mall MA. Mucus obstruction and inflammation in early cystic fibrosis lung disease: emerging role of the IL-1 signaling pathway. Pediatr Pulmonol. 2019 Nov;54(Suppl 3):S5-12.

35 Yang N, Zhang H, Cai X, Shang Y. Epigallocatechin-3-gallate inhibits inflammation and epithelial-mesenchymal transition through the PI3K/AKT pathway via upregulation of PTEN in asthma. Int J Mol Med. $2018 \mathrm{Feb}$; 41(2):818-28.

36 Zhang A, Pan W, Lv J, Wu H. Protective effect of amygdalin on LPS-induced acute lung injury by inhibiting NF- $\kappa \mathrm{B}$ and NLRP3 signaling pathways. Inflammation. 2017 Jun;40(3): 745-51.

37 Płóciennikowska A, Hromada-Judycka A, Borzęcka K, Kwiatkowska K. Co-operation of TLR4 and raft proteins in LPS-induced proinflammatory signaling. Cell Mol Life Sci. 2015 Feb;72(3):557-81.

38 Poltorak A, He X, Smirnova I, Liu MY, Van Huffel C, Du X, et al. Defective LPS signaling in $\mathrm{C} 3 \mathrm{H} / \mathrm{HeJ}$ and $\mathrm{C} 57 \mathrm{BL} / 10 \mathrm{ScCr}$ mice: mutations in Tlr4 gene. Science. 1998 Dec 11; 282(5396):2085-8.

39 Zusso M, Lunardi V, Franceschini D, Pagetta A, Lo R, Stifani S, et al. Ciprofloxacin and levofloxacin attenuate microglia inflammatory response via TLR4/NF-kB pathway. J Neuroinflammation. 2019 Jul 18;16(1):148.

40 Lu YC, Yeh WC, Ohashi PS. LPS/TLR4 signal transduction pathway. Cytokine. 2008 May; 42(2):145-51.

41 Liu G, Fan G, Guo G, Kang W, Wang D, Xu $\mathrm{B}$, et al. FK506 attenuates the inflammation in rat spinal cord injury by inhibiting the activation of NF- $\mathrm{kB}$ in Microglia cells. Cell Mol Neurobiol. 2017 Jul;37(5):843-55. 